\title{
ECONOMIC BENEFITS OF ŠUMAVA NATIONAL PARK
}

\author{
Josef Stemberk ${ }^{1}$
}

DOI: https://doi.org/10.31410/ITEMA.2020.73

\begin{abstract}
The main task of nature protection is to preserve or improve the current state of nature. Thus, it might seem that the economic benefits of the national park are not important for the management of the protected area, but calculating the economic benefits of protected areas for the region improves its acceptance among locals and visitors, as well as political and economic actors.

From 2017 to 2019, Šumava National Park (Bohemian Forest National Park) in the Czech Republic and Nationalpark Bayerischer Wald (Bavarian Forest National Park) were subjected to extensive socio-economic monitoring, which included, among other things, research focusing on the economic benefits that visitors brought to both national parks. This article presents the results of research of the regional economic benefits that visitors brought to Šumava National Park compared with those in Bavarian Forest National Park, although the methods and findings were not absolutely identical and therefore difficult to compare.
\end{abstract}

Keywords: Šumava national park, Economic benefits, Acceptance.

\section{INTRODUCTION}

$\mathrm{F}$ Tirst of all, national parks are a classic tool for large-scale nature protection. After some development, they currently focus on the protection of natural processes. It is a difficult task not only in Central Europe, where it is a particularly challenging task as nature and landscape have been influenced by human use in the long-term. Land use in national parks is limited due to nature conservation, which is often understood as an intervention in spatial planning. Local residents, including political leaders, usually accept national parks with their main functions only reluctantly and see them as a hindrance to regional development. On the other hand, national parks as major natural attractions are among the most sought-after destinations. As a result, their contribution to regional development and its economic benefits is beyond reasonable doubt. This contribution aims to show the economic benefits generated by Sumava National Park, which is the largest national park in the Czech Republic.

\section{a. Šumava National Park}

Šmava National Park was declared in 1991 on an area of 69,000 ha and thus became not only the largest national park in the Czech Republic, but also one of the largest national parks in Central Europe. It stretches in a strip up to $26 \mathrm{~km}$ wide along the Czech-German border in the length of $70 \mathrm{~km}$ and its southern tip touches the Czech-Austrian border. More than $80 \%$ of the territory is covered by forests with numerous fragments of primeval forests. The most valuable are climax mountain spruce forests located in the highest parts of the mountains and in vast Sumava plains at an altitude of about $1,000 \mathrm{~m}$. Numerous peat bogs and wetlands covering about 3,500 ha are protected under the Ramsar Convention on Wetlands. The whole Sumava

University Hradec Kralove, Rokitanského 62, 50003 Hradec Králové III, Czech Republic 
National Park area is also protected as a Natura 2000 area. According to the IUCN (International Union for Conservation of Nature) criteria, Šumava National Park is included in Category II (Dudley, 2008). The natural (non-intervention) zone covers $27.7 \%$ of the area, i.e., over 15,000 ha. Together with the adjacent Šumava Protected Landscape Area, the area is part of a network of biosphere reserves within the UNESCO Man and the Biosphere Programme. Today, this landscape features both natural values and landscape attractions, in which many traces of the original colonization effort have been preserved. (Těšitel et al, 2005)

The formation of the natural values of the Šumava was significantly influenced by its demographic development. The forested border mountains were inhabited much later than other areas and significantly so only in the 19th century. The displacement of the predominantly German population after World War II and the launch of the Iron Curtain on the Czechoslovak western border after 1948 caused a great discontinuity of socio-economic development in the area. The resulting significant decline in population and the decision to close the area to ordinary people led to the demise of numerous settlements. The only surviving economic activities, i.e., agriculture and forestry, were carried out here in their extensive form. Employment in state-owned enterprises in the primary sector placed low demands on the education of workers, which was reflected in the demographic composition of the population. The educational structure was lower than average. Further economic development of the area was enabled only after the fall of the Iron Curtain and the subsequent establishment of the Sumava National Park when tourism has become the most significant economic sector.

\section{METHODS}

In 2017, a socio-economic monitoring system was introduced in Šumava National Park, which, in addition to quantitative monitoring of the number of visitors, collected qualitative data from questionnaire surveys among the public (Transboundary socio-economic monitoring..., 2020). The surveys focused on both the acceptance of Šumava National Park among the locals and the economic benefits of visitors, which will be discussed in this contribution.

In 2018 and 2019, visitors to Šumava National Park were interviewed in order to find out their expenses in the region. This was done in order to calculate the economic effects of tourism in Šmava National Park based on the number of visitors.

A highly structured questionnaire containing 31 closed as well as open questions, which was available in Czech, German and English, was used. Furthermore, face-to-face interviews were conducted by trained staff from both Šumava National Park and Bavarian Forest National Park. The survey took place at 23 locations in Šumava National Park, for a total of 27 days from June 2018 to May 2019, both on weekdays and on weekends and holidays. The answers of the respondents were recorded in an analogue questionnaire and subsequently converted into the electronic form. The interview took an average of 15 minutes. All visitors over the age of 15 who passed interview points were asked to participate in the survey. A total of 549 complete, error-free questionnaires were obtained and could be evaluated (the rejection quota was around $34.8 \%)$.

\section{a. Visitor counting}

The permanent counting of visits using people counting devices took place from 24th November 2017 to 23rd November 2018 at 34 different locations in Šumava National Park. Another standardized counting of people at 66 entrances to Šumava National Park was 
conducted by Šumava National Park's collaborators. Data from people counting devices were used to calculate the number of visits in comparison with calculations performed by staff. (More details in: Transboundary socio-economic monitoring..., 2020)

\section{b. Regional economic benefits}

In order to ensure comparability with studies in other, especially Central European national parks, including the neighbouring Bavarian Forest National Park, regional economic benefits were determined according to the methodology developed in the study by Job et al. (2008).

\section{RESULTS}

\section{a. Socio-demographic characteristics of the interviewees}

According to the type of visitors, $69.7 \%$ of the interviewed were hikers, $14.8 \%$ were cyclists or MTB cyclists and $8.5 \%$ were cross-country skiers. The remaining $7.0 \%$ of respondents were runners, lovers of Nordic Walking or other users (snowshoe hikers, water sportsmen, etc.). $55.6 \%$ of respondents were men, $44.4 \%$ were women. On average, the respondents were 47 years old. A total of $26.9 \%$ of respondents had children with them (0-12 years). $9.7 \%$ of respondents were walking one or more dogs. The majority of dogs $(89.3 \%)$ were on a leash at the time of questioning.

Only $18 \%$ of respondents were residents or cottage owners from the Šumava National Park region, i.e., locals. Over $80 \%$ of respondents were tourists (with $63 \%$ of overnight guests and $19 \%$ day-trippers). Of course, a higher proportion of overnight guests have an impact on regional economic calculations, as they spend more money in the region than day-trippers (Arnberger et al., 2015).

More than half of the visitors (54.6\%) are employees or office workers, about 20\% (21.3\%) are retirees, about $14.7 \%$ are businesspeople, $4.2 \%$ students, $3.8 \%$ are on their maternity leave and others make $1.4 \%$. More than $40 \%(42.2 \%)$ of the respondents completed university or higher education and even $44.2 \%$ passed the school-leaving examination. About $4.4 \%$ completed higher vocational education. Only $9.2 \%$ of visitors stated that they had a lower than secondary education (basic, without an apprenticeship certificate, etc.). When compared with the educational structure of the population of the entire Czech Republic, visitors to Sumava National Park boast of a higher level of education than the national average, especially when it comes to the university level (Source: Czech Statistical Office, 2019).

Approximately $80 \%$ of respondents answered a voluntary question regarding their gross domestic income, and a total of $45.6 \%$ of households had a gross monthly income of CZK 30,000 to 59,999 (Table 1 ).

Table 1. Gross monthly income of households in Šumava National Park.

\begin{tabular}{|l|l|}
\hline Šumava NP- gross monthly income of households in CZK & Share in \% \\
\hline$<14,999$ & 5,4 \\
\hline $15,000-29,999$ & 25,1 \\
\hline $30,000-44,999$ & 26,2 \\
\hline $45,000-59,999$ & 19,4 \\
\hline $60,000-74,999$ & 10,4 \\
\hline $75,000-89,999$ & 4,5 \\
\hline
\end{tabular}




\begin{tabular}{|l|l|}
\hline $90,000-104,999$ & 5,0 \\
\hline $105,000-119,999$ & 1,8 \\
\hline $120,000-134,999$ & 0,5 \\
\hline $135,000-149,999$ & 0,2 \\
\hline$>150,000$ & 1,6 \\
\hline Total & 100,0 \\
\hline
\end{tabular}

Source: Transboundary socio-economic monitoring, 2020.

\section{b. Attitude to the 'national park' status}

Almost all respondents $(98.4 \%)$ knew they were in a protected area. The majority of these respondents $(90.4 \%)$ were able to correctly state the term "national park" when asked about a specific type of protected area. For just over a third of the visitors (35.9\%) who stated national park in the previous question, the fact that it is a national park played a very large or large role for their visit on the day of the survey. 3.5\% of all respondents stated that they would not come if Šumava National Park did not exist.

In order to ensure comparability with research in other national parks, the concept of affinity with national parks was taken over from Job et al. (2003) in a slightly modified form. The national park visitor in the narrower sense was defined according to three questions:

(1) Do you know that you are in a protected area? (a closed question)

(2) If yes, what is its name? (an open question)

(3) What role did the national park status of this area play for your visit today? (a closed question)

According to the above mentioned view, the national park visitor in the narrower sense knows that he is in a protected area, he can specifically name the national park he or she is visiting and its protection status, and the national park status plays a very large or large role for him of her in deciding to visit this area on the day of questioning. Almost a third of all respondents $(31.9 \%)$ fell into the category of the national park visitor in the narrower sense.

\section{c. Number of visitors}

In total, about $1,840,000$ visitors were counted in Šumava National Park during the monitored period (1 year). The survey participants comprised of $63.4 \%$ of overnight guests, $18.9 \%$ daytrippers, and $17.7 \%$ of local residents.

In order to determine the number of visitors for each type of visitor, the share of the respective types of visitors was divided according to the affinity for the national park (yes / no national park visitor in the narrow sense).

Table 2. Distribution and visitor number according to the type of visitors and affinity for the Šumava National Park

\begin{tabular}{|c|c|c|c|}
\hline \multirow{2}{*}{$\begin{array}{l}\text { Type of visitor according to the affinity to } \\
\text { the national park }\end{array}$} & \multicolumn{2}{|c|}{ Respondents } & \multirow{2}{*}{$\begin{array}{l}\text { Number of visitors } \\
\text { in } 017 / 2018\end{array}$} \\
\hline & Number & Per cent & \\
\hline $\begin{array}{l}\text { Overnight guests: NP visitors in the } \\
\text { narrower sense }\end{array}$ & 109 & 20.2 & 370924 \\
\hline Overnight guests: other NP visitors & 236 & 43.7 & 803101 \\
\hline
\end{tabular}




\begin{tabular}{|l|l|l|l|}
\hline $\begin{array}{l}\text { Day-trippers: NP visitors in the narrower } \\
\text { sense }\end{array}$ & 30 & 5.6 & 102089 \\
\hline Day-trippers: other NP visitors & 70 & 13.0 & 238208 \\
\hline $\begin{array}{l}\text { Local residents/cottage owners: NP } \\
\text { visitors in the narrower sense }\end{array}$ & 33 & 6.1 & 112298 \\
\hline $\begin{array}{l}\text { Local residents/cottage owners: other NP } \\
\text { visitors }\end{array}$ & 62 & 11.5 & 210984 \\
\hline Total & 540 & 100.0 & 1837605 \\
\hline
\end{tabular}

Source: Transboundary socio-economic monitoring, 2020.

\section{d. Economic effects of visitors}

For individual types of visitors, net expenses for individual categories of expenses were recalculated according to the current rate of Czech value added tax.

Table 3. Day expenditures (mean value, net) of visitors according to categories in the national park region

\begin{tabular}{|c|c|c|c|c|c|c|c|}
\hline 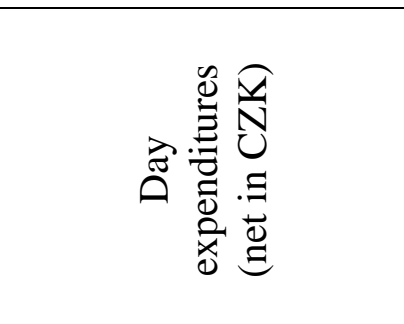 & 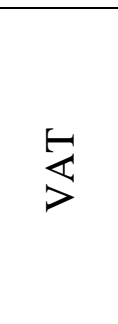 & 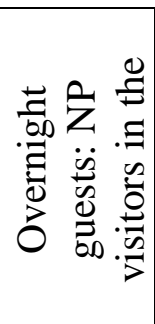 & 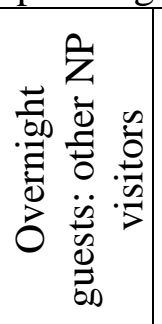 & 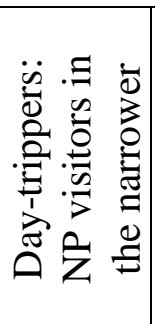 & 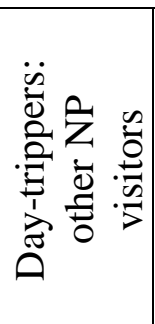 & 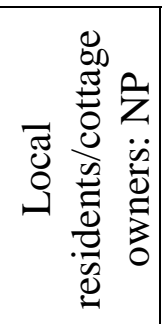 & 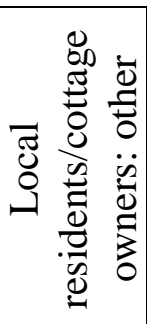 \\
\hline Accommodation & $15 \%$ & 353.7 & 364.1 & - & - & - & - \\
\hline $\begin{array}{l}\text { Food / soft drinks in } \\
\text { accommodation and } \\
\text { catering facilities }\end{array}$ & $15 \%$ & 152.8 & 141.6 & 161.6 & 138.6 & 86.0 & 98.6 \\
\hline $\begin{array}{l}\text { Alcoholic beverages in } \\
\text { accommodation and } \\
\text { catering facilities }\end{array}$ & $21 \%$ & 27.7 & 38.3 & 19.0 & 15.9 & 8.7 & 14.8 \\
\hline $\begin{array}{l}\text { Foodstuffs in shops } \\
\text { (including own food) }\end{array}$ & $18 \% \#$ & 35.4 & 34.2 & 10.9 & 5.1 & 17.4 & 34.1 \\
\hline Books, magazines & $10 \%$ & 1.4 & 3.8 & 3.8 & - & 1.0 & 0.4 \\
\hline $\begin{array}{lr}\begin{array}{l}\text { Other } \\
\text { alcoholic }\end{array} & \text { purchases: } \\
\text { souvenirs, } & \text { sports } \\
\text { equipment, etc. }\end{array}$ & $21 \%$ & 23.6 & 20.4 & 16.8 & 18.3 & 12.9 & 4.8 \\
\hline Public transport & $10 \%$ & 12.1 & 5.0 & 35.0 & 13.5 & 9.0 & 8.4 \\
\hline Parking fees & $21 \%$ & 8.1 & 7.9 & 8.0 & 10.9 & 12.5 & 7.3 \\
\hline $\begin{array}{l}\text { Refuelling (in the } \\
\text { region) }\end{array}$ & $21 \%$ & 13.7 & 24.8 & 29.4 & 29.1 & 12.8 & 36.1 \\
\hline $\begin{array}{l}\text { Rental of sports } \\
\text { equipment, etc. }\end{array}$ & $21 \%$ & 9.3 & 6.9 & - & - & - & - \\
\hline Tickets and admission & $15 \%$ & 17.2 & 13.3 & 8.3 & 1.2 & - & - \\
\hline $\begin{array}{l}\text { Municipal taxes / guest } \\
\text { card }\end{array}$ & $15 \%$ & 16.8 & 16.1 & - & - & - & - \\
\hline $\begin{array}{l}\text { Spa treatments } \\
\text { doctor's fee }\end{array}$ & $15 \%$ & 1.8 & 2.4 & - & - & 7.9 & 1.0 \\
\hline
\end{tabular}




\begin{tabular}{|l|c|c|c|c|c|c|c|}
\hline Other expenses & $18 \% *$ & 0.6 & - & - & - & - & - \\
\hline Lump sum & $18 \%^{\wedge}$ & 11.4 & 80.7 & - & 6.1 & - & - \\
\hline Total & & $\mathbf{6 8 5 . 8}$ & $\mathbf{7 5 9 . 5}$ & $\mathbf{2 9 2 . 8}$ & 238.8 & $\mathbf{1 6 8 . 1}$ & $\mathbf{2 0 5 . 5}$ \\
\hline $\mathrm{N}$ & & 109 & 236 & 30 & 70 & 33 & 62 \\
\hline
\end{tabular}

Notices: \# Mixed value added tax because food is taxed differently; * Mixed value added tax for all categories except accommodation; ^ Mixed value added tax for all categories.

Source: Transboundary socio-economic monitoring, 2020.

Table 4 shows a summary of average total expenditure per person according to the type of visitor and affinity for the national park.

Table 4. Overview of visitor expenses by type of visitor and affinity for the national park (per person): gross and net, Visitors to the national park in the narrower sense

\begin{tabular}{|l|c|c|}
\hline $\begin{array}{l}\text { Type of visitor according to affinity } \\
\text { for the national park }\end{array}$ & $\begin{array}{c}\text { Daily expenditures (gross) } \\
\text { in CZK }\end{array}$ & $\begin{array}{c}\text { Daily expenditures (net) } \\
\text { in CZK }\end{array}$ \\
\hline $\begin{array}{l}\text { Overnight guests: NP visitors in the } \\
\text { narrower sense }\end{array}$ & 794.3 & 685.8 \\
\hline Overnight guests: other NP visitors & 882.3 & 759.5 \\
\hline $\begin{array}{l}\text { Day-trippers: NP visitors in the } \\
\text { narrower sense }\end{array}$ & 339.5 & 292.8 \\
\hline Day-trippers: other NP visitors & 278.7 & 238.8 \\
\hline $\begin{array}{l}\text { Local residents/cottage owners: NP } \\
\text { visitors in the narrower sense }\end{array}$ & 196.1 & 205.5 \\
\hline $\begin{array}{l}\text { Local residents/cottage owners: } \\
\text { other NP visitors }\end{array}$ & 240.7 & 208.1 \\
\hline
\end{tabular}

Annual turnovers were calculated from daily expenditures according to the types of visitors and affinity for the national park (daily expenditures * number of visitors - Table 5). The total gross annual turnover was CZK 1,177 million and the net turnover was CZK 1,013 million (Table 5).

Table 5. Overview of gross and net annual sales by type of visitor and affinity for the national park: Visitors to the national park in the narrower sense

\begin{tabular}{|l|c|c|}
\hline $\begin{array}{l}\text { Type of visitor according to affinity for the } \\
\text { national park }\end{array}$ & $\begin{array}{c}\text { Daily expenditures } \\
\text { (gross) in CZK }\end{array}$ & $\begin{array}{c}\text { Daily expenditures } \\
\text { (net) in CZK }\end{array}$ \\
\hline $\begin{array}{l}\text { Overnight guests: NP visitors in the narrower } \\
\text { sense }\end{array}$ & 294638369 & 254369033 \\
\hline Overnight guests: other NP visitors & 708578908 & 609935368 \\
\hline Day-trippers: NP visitors in the narrower sense & 34658705 & 29891314 \\
\hline Day-trippers: other NP visitors & 66394257 & 56881851 \\
\hline $\begin{array}{l}\text { Local residents/cottage owners: NP visitors in the } \\
\text { narrower sense }\end{array}$ & 22026683 & 18877366 \\
\hline Local residents/cottage owners: other NP visitors & 50782668 & 43358065 \\
\hline Total & 1177079590 & 1013312997 \\
\hline
\end{tabular}

Source: Transboundary socio-economic monitoring, 2020.

The group of overnight guests generated the largest share of economic impacts. Their share in individual economic indicators was more than $80 \%$. The expenditures of this visitor group for 
accommodation and meals contributed to the total production (as well as on other monitored economic variables) by more than $50 \%$.

\section{e. Calculation of economic benefits}

Melichar \& Pavelčík (2020) calculated the economic benefits of Šumava National Park using input-output analysis. In 2018, Šumava National Park was visited by 1,837,605 visitors, whose expenditures of CZK 1.18 billion resulted in an increase in regional production (turnover) by a total of CZK 1.4 billion, including multiplier effects. Direct effects on primary providers of tourist products and services (in the sectors of accommodation, catering, transport, retail, refuelling, etc.) amounted to CZK 764 million. Of the total impact on production, CZK 484 million fell on the total increase in gross value added, or gross domestic product of the region's economy (Table 6).

Table 6. Total economic impacts of visitors to Šumava National Park: impacts on production, GDP, regional income, wages of employees and employment (in CZK, prices in 2018)

\begin{tabular}{|l|c|c|c|}
\hline Type of economic effect & Direct impacts & Indirect impacts & Total impacts \\
\hline Impacts on production & 763666949 & 607301522 & 1370968471 \\
\hline Impacts on GDP & 290065737 & 193994589 & 484060326 \\
\hline Impacts on regional income & 204761991 & 135629652 & 340391642 \\
\hline $\begin{array}{l}\text { Impacts on employees' wages and } \\
\text { salaries }\end{array}$ & 120947991 & 54571391 & 175519382 \\
\hline $\begin{array}{l}\text { Impacts on employment (Number } \\
\text { of full-time jobs) }\end{array}$ & $385^{*}$ & $164 *$ & $549 *$ \\
\hline
\end{tabular}

Source: Melichar \& Pavelčík (2020).

Expenditures of visitors to Šumava National Park also contributed in 2018 to an increase in income in the region of CZK 340 million. Of this amount, CZK 176 million was the wage income of employees of direct providers of tourist products and services and their subcontractors. At the same time, visitors' expenditures contributed to the creation or preservation of 549 jobs in the Šumava National Park region.

\section{CONCLUSION}

Visitors and tourism generate significant regional and economic effects in the peripheral area of the Czech-German border, in Šumava National Park. The annual expenditure (2018) of all visitors $(1,837,605)$ represents CZK 1.18 billion (approximately $€ 47.1$ million). If this data is compared with the neighbouring Bavarian Forest National Park, where the annual gross turnover is $€ 52.4$ million with a calculated annual attendance of 1,361,367 people (Bavarian Forest National Park Administration, 2020), then in both cases tourism creates a significant regional economic effect. (See Table 7, compare with Table 5).

Table 7. Overview of gross and net annual sales by type of visitor and affinity for Bavarian Forest National Park.

\begin{tabular}{|l|c|c|}
\hline $\begin{array}{l}\text { Type of visitor according to affinity for the national } \\
\text { park }\end{array}$ & Gross turnover in $€$ & Net turnover in $€$ \\
\hline Overnight guests: NP visitors in the narrower sense & 28976778 & 25831947 \\
\hline Overnight guests: other NP visitors & 13741544 & 12359568 \\
\hline Day-trippers: NP visitors in the narrower sense & 3241801 & 2743845 \\
\hline
\end{tabular}




\begin{tabular}{|l|c|c|}
\hline Day-trippers: other NP visitors & 2756098 & 2339899 \\
\hline $\begin{array}{l}\text { Local residents/cottage owners: NP visitors in the } \\
\text { narrower sense }\end{array}$ & 1933278 & 1647156 \\
\hline Local residents/cottage owners: other NP visitors & 1751812 & 1492730 \\
\hline Total & 52401311 & 46415145 \\
\hline
\end{tabular}

Source: Transboundary socio-economic monitoring, 2020.

In Šumava National Park, a socio-economic monitoring system has been gradually introduced since 2018, but the first research of the economic effects of the national park took place in Bavarian Forest National Park as early as 2007 and is repeated about every five years. (See Table 8). The main reasons for the increase in visitor expenditures (especially those of overnight guests) include the rising standard of accommodation facilities, which can also obtain a "National Park Partner" certificate, whose criteria include environmentally friendly operation as well as the support of the Bavarian Forest National Park approach: 'let nature be nature'.

Table 8. Daily expenditures (gross per person), according to the visitor's affinity for the national park.

\begin{tabular}{|l|c|c|c|}
\hline $\begin{array}{l}\text { Type of visitor according to affinity for the national } \\
\text { park }\end{array}$ & $\begin{array}{c}\text { Daily } \\
\text { expenditure } \\
\text { s 2007 } \\
\text { (gross) in } €\end{array}$ & $\begin{array}{c}\text { Daily } \\
\text { expenditures } \\
2013 / 14 \\
\text { (gross) in } €\end{array}$ & $\begin{array}{c}\text { Daily } \\
\text { expenditures } \\
2018 / 19 \\
\text { (gross) in } €\end{array}$ \\
\hline Overnight guests: NP visitors in the narrower sense & 49.6 & 56.2 & 77.7 \\
\hline Overnight guests: other NP visitors & 49.6 & 56.2 & 71.9 \\
\hline Day-trippers: NP visitors in the narrower sense & 12.3 & 13.9 & 18.2 \\
\hline Day-trippers: other NP visitors & 12.1 & 13.7 & 18.5 \\
\hline $\begin{array}{l}\text { Local residents/cottage owners: NP visitors in the } \\
\text { narrower sense }\end{array}$ & 9.1 & 10.4 & 8.2 \\
\hline Local residents/cottage owners: other NP visitors & 6.1 & 6.9 & 7.5 \\
\hline
\end{tabular}

Source: Transboundary socio-economic monitoring, 2020.

Overall, the results in both neighbouring and comparable national parks show that soft forms of tourism, where the main reason for the visit is to stay and observe nature, bring significant economic benefits to the region. These results refute the general myth that nature conservation is at odds with socio-economic development (Těšitel et al., 2005) and at the same time support the claim that nature tourism, which combines nature experience with relieving the burden on nature and the environment, and with generating economic benefits, greatly increases the acceptance of protected areas (Job et al, 2005).

\section{ACKNOWLEDGMENT}

I would like to thank all my colleagues working together on the project "Introduction of a transboundary socio-economic monitoring system in the National Parks of Šumava and Bavarian Forest" from the Šumava National Park Administration, Bavarian Forest National Park Administration and the methodical and supervisor work of experts from the University of Natural Resources and Life Sciences, Vienna (BOKU). The common Czech-Bavarian project was supported by the European Union. 


\section{REFERENCES}

Dudley, N., (2008). Guidelines for Applying Protected Area Management Categories. Gland, Switzerland: IUCN. ISBN 978-2-8317-1086-0

Těšitel J., Kušová D., Matějka K., Bartoš M. (2005). Lidé v biosférických rezervacích /People in biosphere reserves. České Budějovice, Czech Republic: Ústav systémové biologie a ekologie Akademie věd České republiky.

Arnberger, A., Allex, B., Preisel, H., Eder, R. (2015): Sozioökonomisches Monitoring Nationalpark Bayerischer Wald: Befragung und Besucherzählung 2013/2014. Interner Endbericht.

Job, H., Mayer, M., Woltering, M. (2008). Die Destination Nationalpark Bayerischer Wald als regionaler Wirtschaftsfaktor. Germany: Bavarian Forest National Park Administration.

Job, H., Metzler, D., Vogt, L. (2003). Inwertsetzung alpiner Nationalparke. Eine regionalwirtschaftliche Analyse des Tourismus im Alpenpark Berchtesgaden. Münchener Studien zur Sozial- und Wirtschaftsgeographie 43.

\section{ADDITIONAL READING}

Melichar J. \& Pavelčík, P. (2020). Evaluation of the economic effects of tourism in Šumava National Park. Charles University/Prague, Czech Republic: Unpublished report.

Transboundary socio-economic monitoring in Šumava and Bavarian Forest National Parks in the years 2017-2019. (Final report) (2020), Šumava National Park Administration/Vimperk, Czech Republic: Šumava National Park Administration (published on-line: https://www.npsumava.cz/sprava-np/seznam-projektu/zavedenipreshranicniho-socioekonomickeho-monitorovaciho-systemu-v-narodnich-parcichsumava-a-bavorsky-les-2/) 